\author{
蒸発源に TiC を用いたゲッタポンプ* \\ 田 畑 三 郎**・岩田稔** \\ (昭和 36 年 4 月 14 日 受理) \\ A Getter Pump with Evaporation Source made of Titanium Carbide \\ Saburo TABATA and Miroru IWATA \\ (The Osaka Industrial Research Institute)
}

A TiC getter pump with evaporation source of TiC heater was made in order to evacuate a coating apparatus of mirror of $2.0 \mathrm{~m}$ diameter.

According to previous report ${ }^{1)}$ the $\mathrm{TiC}$ bars were inserted into the ordinary alumina crucible which was a reservoir of molton metal. This time $\mathrm{Ti}$ is used in a wire form and is fed constantly onto a TiC heater. The conclusions are as follows.

1) $\mathrm{TiC}$ is useful as $\mathrm{Ti}$ evaporating heater.

2) When an oil diffusion pump was operated as a fore pump, the compound rate of exhaustion was: greatly affected by back diffusion of oil vapour. When the valve between the oil diffusion pump and the getter pump was appropriately opened, the rate of exhaustion was increased to a value 25 times as great as the rate when the valve was fully opened.

3) A getter pump is not only useful for very high vacuum apparatuses with metal seals, but also' the conventional vacuum apparatus with synthetic rubber seals.

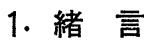

ゲッタイオンポンプは金属蒸発によるものとスパッタ によるものとの 2 種に分類される。前者はゲッタ物質を 加熱蒸発により、後者は sputtering によって苲気化さ せゲッタ効果を利用して排気容器内を高真空に維持させ る。金属蒸発に用いられるゲッタ物質 ( $\mathrm{Ti}, \mathrm{Ca}, \mathrm{Ba}$, 等) は排気特性がガスによって異り選択的排気を行なう。又 いづれの物質の場合でも非活性ガスに対するゲッタ効果 は少ないのでイオンポンプ効果を併用してこれを取除い ている。

蒸発法によるポンプはスパッタ法に比べてポンプに不 可欠な性能、すなわち作動の安定性と長寿命の点でおと るにもかかわらず、現在なおこの欠陷を除くために多く の研究 ${ }^{2,3,4)}$ がなされているのは同一排気速度に対する二 ストが後者に比べて安価であること、および小型で済先 ことに原因している。蒸発法によるポンプに用いられて いる電子衝撃法による蒸発源の改良について多くの研究

* 1960年10月応物関係連合講演会で発表

** 工業技術院 大阪工業技術試験所第 3 部
がなされ、その寿命と作動の安定性について種々の試み が行われている。吾々はかつて種々の金属の大量蒸着法 の研究 ${ }^{5,6)}$ において $\mathrm{TiC}$ 堂登源に用いたが、同時に T の蒸発も試みた。TiCヒータは Ti に対して耐食性よ く蒸発源として有能であることを認めた。本交では蒸発 法に属するゲッタポンプに TiC 克接加熱する蒸発源 を用いた場合、(ゲッタには Ti 学使用)の蒸発源の耐 食性と形状扮よび排気特性について検討した結果を報告 する。ゲッタポンプに油拡散ポンプを併用した場合、酸 素、窒素、空気に対する排気速度が著しく高められるこ とは知られている。 ${ }^{7,8)}$ 吾々の目的は $2.5 \mathrm{~m}$ 反射鏡蒸着 装置にゲッタポンプを設置してその排気能率を高めるこ とである。ここではゲッタポンプに油拡散ポンプを協力 させることを原則として実験を進めた。

\section{2. 実験装置}

ゲッタポンプ本体の概略をFig. 1 に写真它Fig.2 2 示す。 蒸発源およびポンプ本体の特徴は次の通りである。す なわち

1) 真空シールは可動部分も含めて全て合成ゴムを用? 


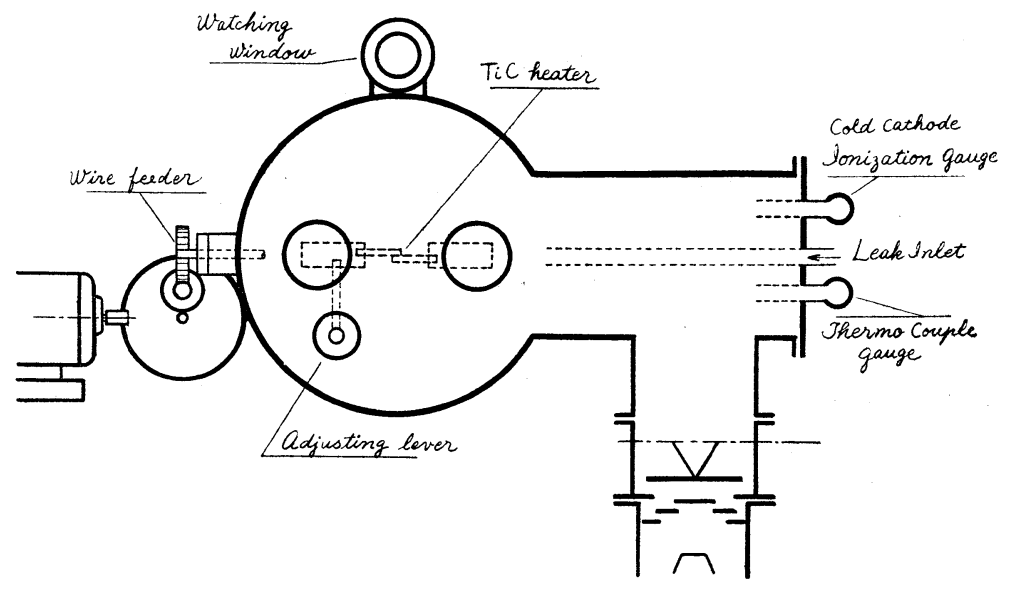

Fig. 1 Schematic diagram of getter-pump.

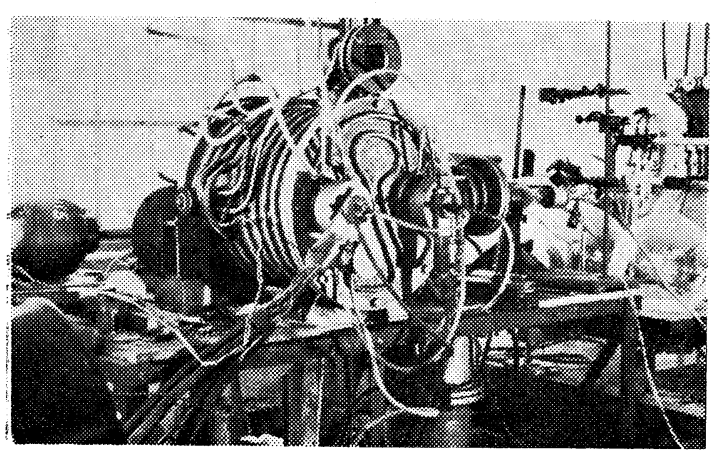

Fig. 2 Photograph of getter-pump.

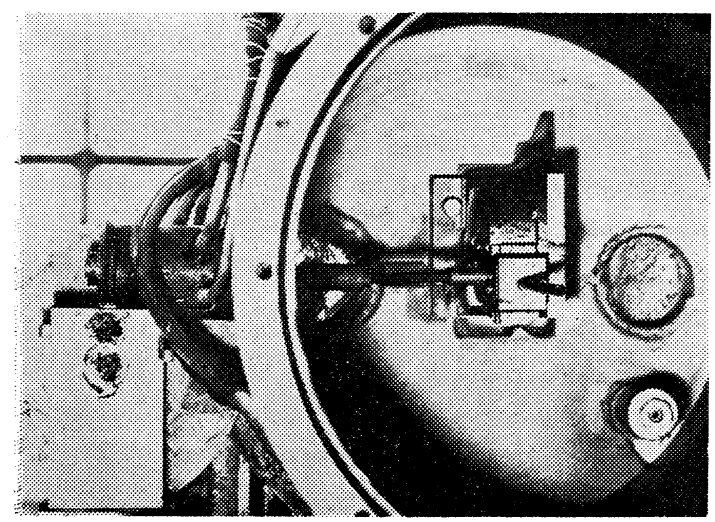

Fig. 3 Feeding device of the wire.

いた。

2) Ti 線はローラによって撩取枠から引き出し案内 管によってヒータ面に送る*。ローラは外部から 变速装置によって駆動する。（Fig.3）

3) ヒータ導入電極は直径 1 时の真鍮棒でこれにター ミナルを固定する。ターミナルは水で泠却してい 万。

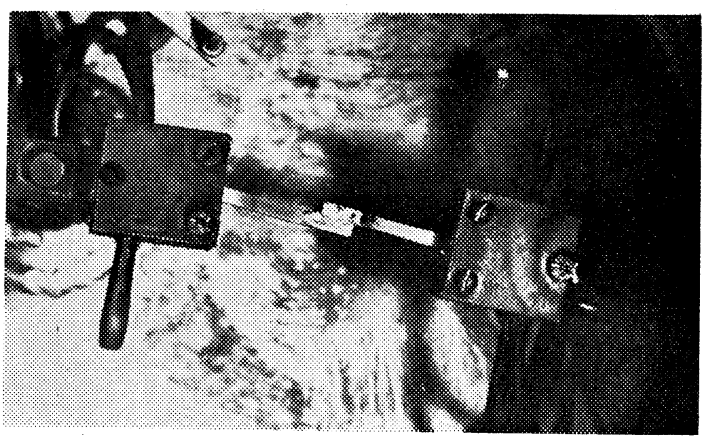

Fig. 4 The TiC heater and water cooled electrodes.

4）ヒータの熱消費 $[1.6 \mathrm{~kW}(400 \mathrm{~A}) \sim 3.5 \mathrm{~kW}(700 \mathrm{~A})]$ が大きいので本体各部は水冷军行なう。特にシー ル部は効果的に水冷を施した。

5) ポンプ本体は $290 \mathrm{~mm} \not p \times 330 \mathrm{~mm}$ の鉄 ( $\mathrm{Ni}$ 鍍金) 製である。

6) $\mathrm{TiC}$ は $4.5 \times 4.5 \times 55 \mathrm{~mm}$ の棒 2 本を用い、たが いの一端を接触させて他端をリードターミナルで 保持宁る。 (Fig. 4)

油拡散ポンプ（有効径 4 时、分溜型。1 $0^{-5} \mathrm{mmHg}$ にお ける排気速度 $170 \mathrm{l} / \mathrm{s})$ およびバルブ類は自製である。

真空計はペンニングゲージ（フィリップス社製）を用 いた。Fig. 1 に示すごとく補助真空用側管の一端で測定 てた。

* 線材 $(\mathrm{D}=0.5 \mathrm{~mm})$ は燒鈍しない。捲取枠によるカ ーリングはあまり影響がなく、したがって Ti 線の ヒータからの外れはほとんどなかったが、案内管と 線材の溶着はこの機構では本質的にのがれることが できない。然しヒータと案内管の距離を調節すれば 支障はなかった。 


\section{3. 実験および考察}

補助排気装置による到達真空度は $1.4 \times 10^{-5} \mathrm{mmHg}$, ポンプ本体のリーク量は $<1 \times 10^{-2}$ lusec である。

補助ポンプによる到達真空度で $\mathrm{TiC} ヒ$ 一を通電加熱 する。 $6.5 \mathrm{~V}, 350 \mathrm{~A}$ で所要の蒸発温度が得られる。Ti の蒸発を開始すると約 15 秒以内慎空度が落ち、(3〜 $7.5 \times 10^{-5} \mathrm{mmHg}$ ) 以後になると排気効果が現われて急 激によくなる。Fig. 5 はその排気曲線の一例である。 領域 $\mathrm{A}$ は補助ポンプの到達真空度、送り速度 $24 \mathrm{mg} / \mathrm{min}$ で蒸発学開始すると放出ガスのために急激に落ち約 15 秒 で $3 \times 10^{-} \mathrm{mmHg}$ になるが、直ちに上り約 50 秒後 $5.4 \times 10^{-6} \mathrm{mmHg}$ になる。ここからゆるやかなカーブ を画いて約 5 分後 $4.8 \times 10^{-6} \mathrm{mmHg}$ になり約 20 分後に おいてもほとえど変化しない。

送り速度を約 $30 \mathrm{mg} / \mathrm{min}$ にして同様に行なうと到達真 空度は徐々に向上して最良の場合約 $2 \times 10^{-6} \mathrm{mmHg}$ に なる。

ポンプ外壁の温度は $18^{\circ} \mathrm{C}$ から $25^{\circ} \mathrm{C}$ に上昇する。 特に加熱の著しい導入電極のシール部、䕊、送り軸の部 分を独立して水冷する。またターミナルの接触抵抗す昇 温の原因であるのでなるべく小さくすると約 $20^{\circ} \mathrm{C}$ で安 定する。しかし到達真空度はほぼ $2 \times 10^{-6} \mathrm{mmHg}$ 以 上にならない。

次にグッタポンプを油拡散ポンプから絶縁させて作動 する。すなわち $3.6 \times 10^{-5} \mathrm{mmHg}$ から $3.7 \times 10^{-6} \mathrm{mmHg}$ に向上したとき油拡散ポンプをバルブで閉じる。Tiの蒸 発を続行すると約 12 分後 $2.8 \times 10^{-6} \mathrm{mmHg}$ になる。しか しここから次第に真空度が落ち 20 分後に $3 \times 10^{-5} \mathrm{mmHg}$, となり、更に劣化の傾向をたどる。ここでバルブを開く と瞬時によくなり $10^{-7} \mathrm{mmHg}$ に入るが数分後には再び $3.7 \times 10^{-6} \mathrm{mmHg}$ に戻って安定する。バルブの開閉它繰 返すと真空度は落ち、次に従前より向上し、そして再び 閉じる前の真空度に戻る。

次にバルブの開閉を加減して拡散ポンプの排気コンダ クタンスを変えて引いてみる。

今 $1.2 \times 10^{-5} \mathrm{mmHg}$ で蒸発を始めると約 4 分後に 2.4 $\times 10^{-6} \mathrm{mmHg}$ の到達圧力に到る。バルブを次第に閉じ ると真空度は徐々に向上し、ほとえど閉じ終る頃になる と $7.1 \times 10^{-7} \mathrm{mmHg}$ になる。この場合の一例を Fig. 6 に 示す。

$5.1 \times 10^{-5} \mathrm{mmHg}$ で蒸発を始め約 3.5 分後 $5.4 \times 10^{-6}$ $\mathrm{mmHg}$ になったとき蒸発を続行しながらバルブを閉じ てゆく。眓の（a）はこの操作によって得られた領域で ある。(b) はバルブを完全に閉じだ場合ゲッタポンプだ 㳡の領域である。そしてバルブを（a）の場 合に等しく

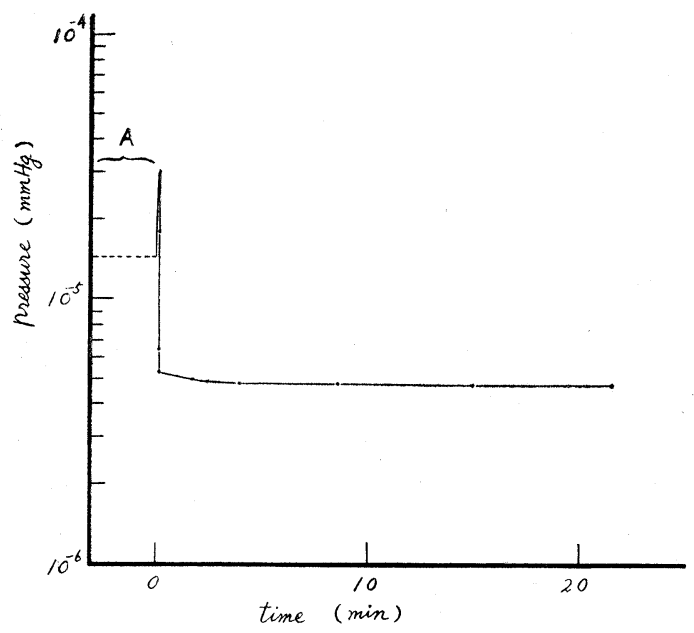

Fig 5 Pump down curve for normal air when the valve was fully opened and the diffusion pump without baffle.

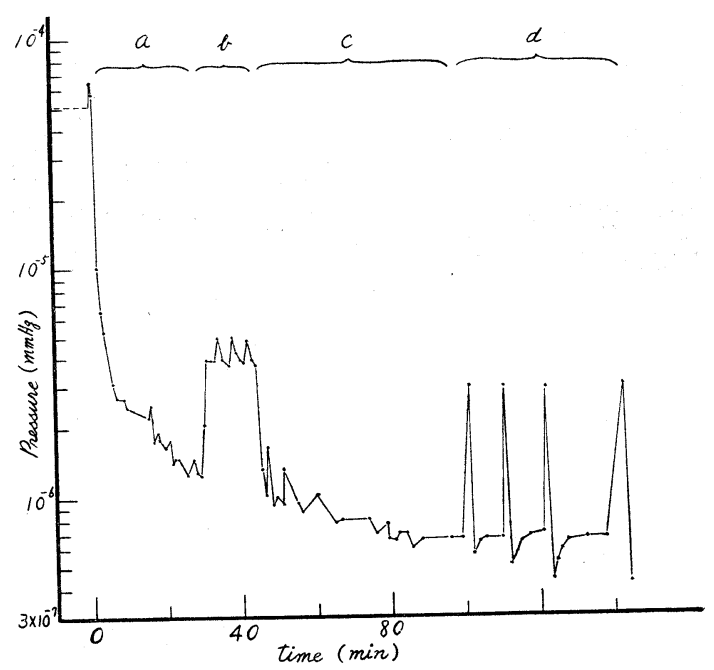

Fig. 6 Pump down curve for normal air when the valve was appropriately opened and the diffusion pump without baffle (region a), valve closed (region $b$ ) and again the valve was appropriately opened (region $\mathrm{c}$ ), and pressure variation when the valve was closd and after opened in vicinity of final vacua( region $d$ ).

開けると（c）の領域に入り約 80 分後には $6.6 \times 10^{-7} \mathrm{~mm}$ $\mathrm{Hg}$ に到る。バルブの開き具合を到達真空度が最良にな るよう調節した場合である。このときの拡散ポンプの排 気速度はバルブの有効断面積の比から見ると約 $S=1 / 7$ に減少していることになる。 


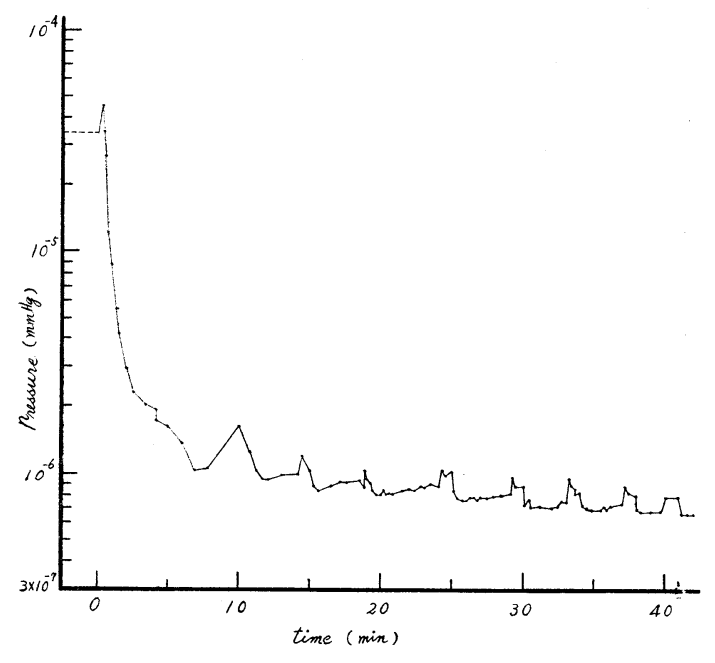

Fig. 7 Pump down curve for normal air when the valve was appropriately opened and the diffusion pump with baffle.

Fig. 5 と Fig. 6 の真空度線はバルブの開き具合の相 異によって得られたものである。吾々の拡散ポンプはバ ルブの弁座をバッフル兼用にして特別なバッフルを装着 していなかった。

Fig. 7 はバッフルを装着した場合の真空度曲線であ る。この場合バルブは約 $S=1 / 2$ の状態に開いている。

$3.4 \times 10^{-5} \mathrm{mmHg}$ で蒸発を始め約 40 分後に $6.8 \times 10^{-7}$ $\mathrm{mHg}$ になった。

Fig. 6 と比較するとバッフルの効果が明らかである。 ここでバルブ fully open, (全開) shutted (閉止) appropriately open (適度に開放)（いずれもバッフル 付き）の場合のそれぞれの排気要素完考慮すると次の関 係がなりたつ。

fully open (全開) の場合の合成排気速度を $S_{1}$ とす ると

$$
S_{1}=S_{\mathrm{d}}+S_{\mathrm{g}}-\left(S_{\mathrm{b}}+S_{\mathrm{l}}\right)
$$

ただし $S_{\mathrm{d}}$; 拡散ポンプの排気速度

$S_{\mathrm{g}}$; ゲッタポンプの排気速度

$S_{\mathrm{b}}$; 油の逆拡散により生ずる負の排気速度

$S_{1} ; \mathrm{Ti}$ 蒸発の際放出ガスおよ びポンプ系の 真リーク,放出ガスなどによる負の排気 速度

Shutted (閉止) の場合の排気速度 $S_{2}$ は

$$
S_{2}=S_{\mathrm{g}}-S_{1}
$$

Appropriately open (適適度に開放) の場合の $S_{3}$ は

$$
S_{3}=S_{\mathrm{g}}+S_{\mathrm{d}^{\prime}}-\left(S_{\mathrm{b}^{\prime}}+S_{\mathrm{l}}\right)
$$

ただし $S_{\mathrm{d}}{ }^{\prime}$; バルブコンダクタンスで決まる拡散ポン プの排気速度

$S_{\mathrm{b}}{ }^{\prime}$ ；バルブコンダクタンスで決まる逆拡散に よる負の排気速度

そして〔1][2][3]はそれぞれの関係を保って真空 度が向上する。 $S_{1}, S_{2}, S_{3}$ ，は既知のリーク量を与えて 求めるべきであるが、一応各真空度における $d p / d t$ 曲線 から見掛けの排気速度として算出すると Fig. 8 の通り になる。

逆拡散による負の排気速度を含めた拡散ポンプの有効 排気速度は〔1][2]および〔3][2]から得られる。 すなわち fully open の場合

$S_{1}-S_{2}=S_{\mathrm{d}}-S_{\mathrm{b}}=1.0 \times 10^{-2} \mathrm{l} / \mathrm{s}\left(4 \times 10^{-6} \mathrm{~mm}\right.$

$\mathrm{Hg}$ において)

Appropriately open $の$ 場合

$S_{3}-S_{2}=S_{\mathrm{d}}{ }^{\prime}-S_{\mathrm{b}}{ }^{\prime}=2.5 \times 10^{-1} l / \mathrm{s}\left(4 \times 10^{-6} \mathrm{~mm}\right.$

Hgにおいて)

$S_{\mathrm{d}}$ と $S_{\mathrm{d}}{ }^{\prime}$ との間には有効断面積比から

同様に

$$
S_{\mathrm{d}} \div 2 S_{\mathrm{d}^{\prime}}
$$

$$
S_{\mathrm{b}} \div 2 S_{\mathrm{b}}
$$

の関係にあると考光る。

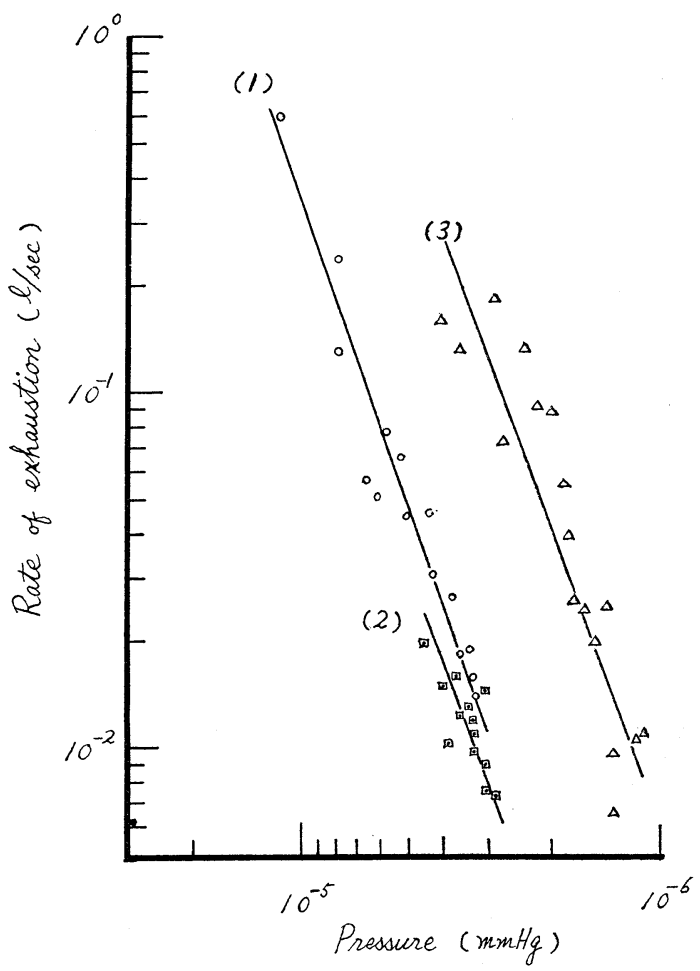

Fig. 8 Apparent rate of exhaustion for normal air when the valve was fully opened( 1$)$, shutted (2), and appropriately opened (3), respectively. 
かくして逆拡散による負の排気速度が約 $1 / 2$ に減ること によって拡散ポンプの有効排気速度は約 25 倍に増加した ことになる。

ゲッタポンプに油拡散ポソプを併用する場合、拡散ポ ンプは単にコンダクタンスを考慮した排気速度でゲッタ ポンプに寄与しているのでなく、ゲッタポンプ内で生成 しゲッタ効果を阻害す "poison"（炭化水素）を取り除 くことによって排気効果を一層強めていると云われ る7。このように考学れば拡散ポンプは一方では" poison" を取除くが他方では逆拡散で入った油はヒータ面で分解 し、これが "poison"となって逆にゲッタポンプの排気 速度に負の効果を与えることは当然考学られる。

$S_{2}=\mathrm{O}$ で到達真空度に達した場合、残留ガスは主に 非活性ガスおよび炭化水素からなって真空度はこの分圧 によって決まる。

バルブが fully open の場合 $S_{\mathrm{d}}$ と $S_{\mathrm{b}}$ はほぼ同じ量 になるので有効速度 $\left(S_{\mathrm{d}}-S_{\mathrm{b}}\right)$ は小さいが Appropriately open の場合は拡散ポンプの排気速度の減少より逆拡 散による負の速度の減少が著しいので $S_{\mathrm{d}}-S_{\mathrm{b}}<S_{\mathrm{d}}{ }^{\prime}-S_{\mathrm{b}}{ }^{\prime}$ となり上述の如き排気特性を示すのであろう。

吾々のポンプはイオンポンプとして働かしていない。

ここで $S_{\mathrm{g}}$ のガス選択性の観点から Fig. 6 (d) 領域 の現象について考察する。

(d) 領域では拡散ポンプをゲッタポンプから切離した 場合しばらくしてバルブを開くと瞬時に従前の真空度よ り向上する現象を示す。

今、活性、非活性ガスはゲッタと拡散ポンプによって 選択排気されていると考光る。 $S_{\text {a }}$ を活性、 $S_{\mathrm{i}}$ を非活性ガ スに対する排気速度とすると $S_{3}$ は

$$
S_{3}=S_{\mathrm{a}}+S_{\mathrm{i}}
$$

ただし

$$
\begin{aligned}
& S_{\mathrm{a}}=S_{\mathrm{g}}+S_{\mathrm{d}{ }_{\mathrm{a}}}-\left(S_{\mathrm{b}{ }_{\mathrm{a}}}+S_{\mathrm{la}}\right) \\
& S_{\mathrm{i}}=S_{\mathrm{d}}{ }^{{ }_{\mathrm{i}}}-\left(S_{\mathrm{b}}{ }^{\prime}{ }_{\mathrm{i}}+S_{\mathrm{li}}\right)
\end{aligned}
$$

で表わされる。

Appropriately open の状態で到達真空度に達した場 合ゲッタポンプの排気速度は大きく放出ガスおよびリー クガスの活性分に見合らだけの排気速度をもつが、更に 逆拡散による影響が減少しているために余力をもってこ れらのガスを排気しているものとすれば

$$
S_{\mathrm{g}} \geq S_{\mathrm{b}}{ }^{\prime}{ }_{\mathrm{a}}+S_{\mathrm{la}}
$$

$S \mathrm{~g}$ は非活性ガスに対して排気効果をもたないから $S_{3}$ は

$$
S_{3}=S_{\mathrm{d}}{ }^{\prime}-\left(S_{\mathrm{bi}}+S_{1 \mathrm{i}}\right)
$$

の関係で釣合っている。すなわち非活性ガスの分圧によ って真空度が決まる。

ここでバルブを閉じると $S_{\mathrm{d}^{\prime}}{ }^{\prime}=S_{\mathrm{b}}{ }^{\prime}{ }_{\mathrm{i}}=\mathrm{O}$
$S_{3}=-S_{1 \mathrm{i}}$

の関係で真空度は次第に落ちてゆく。

$S_{\mathrm{d}}{ }^{\prime}$ がゲッタ面をよごし、その効果を減殺するために 排気速度が減少するものとすればバルブを開いた瞬間は

$S_{\mathrm{d}}{ }^{\prime}{ }_{\mathrm{i}}$ 性定常状態における $S_{\mathrm{d}}{ }^{\prime}{ }_{\mathrm{i}}$ に比べて小さいと考党 られる。したがって極めて短い間、 $S_{3}$ は

$$
S_{3}=S_{\mathrm{d}}{ }^{\prime}-S_{1 \mathrm{i}}
$$

となって排気速度は定常状態より大きくなる。 そして再び一 $S_{\mathrm{di}}{ }^{\prime}$ の影響が時間と共に蓄積される結果 $S_{3}=S_{\mathrm{d}}{ }^{\prime}-\left(S_{\mathrm{b}}{ }^{\prime}{ }_{\mathrm{i}}+S_{\mathrm{li}}\right)$ に戻る。

（d）領域の排気曲線はこの過程はよって生じたのであ ろら。

通常の空気に対して定圧法で実測した排気速度をFig。 9 に示す。リーク導入口と真空度測定管の位置は Fig. 1 に示す通りである。油拡散ポンプはバッフル付き、バル ブは Appropriately open の状態である。このときの油 拡散ポンプの排気速度は約 $30 \mathrm{l} / \mathrm{s}$ であった。

$5 \times 10^{-6} \sim 8 \times 10^{-5} \mathrm{mmHg}$ の間では排気速度は直線 的に変化し $5 \times 10^{-5} \mathrm{mmHg}$ で $1000 \mathrm{l} / \mathrm{s}, 1.2 \times 10^{-5} \mathrm{~mm}$ $\mathrm{Hg}$ で $3000 \mathrm{l} / \mathrm{s}, \quad 5 \times 10^{-6} \mathrm{mmHg}$ で $7000 \mathrm{l} / \mathrm{s}$ の值が得られ た。いずれも Ti の送り速度 $24 \mathrm{mg} / \mathrm{min}$ 一定である。

\section{$\mathrm{TiC}$ 蒸発源}

$\mathrm{TiC}$ 棒は前述の方法でセットし、接触部は TiCペー スト（TiC 粉末十澱粉糊）を挾えで圧着する。ターミナ ルとヒータの間には Mo 板它数枚重ねて挾み、その間の

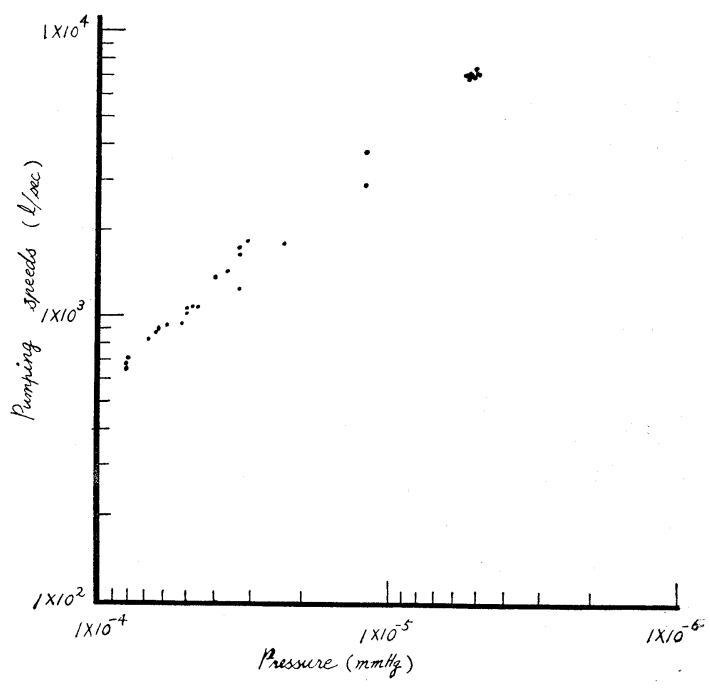

Fig. 9 Pumping speed of getter pump for normal air with oil diffusion pump when the valve was appropriately opened. 


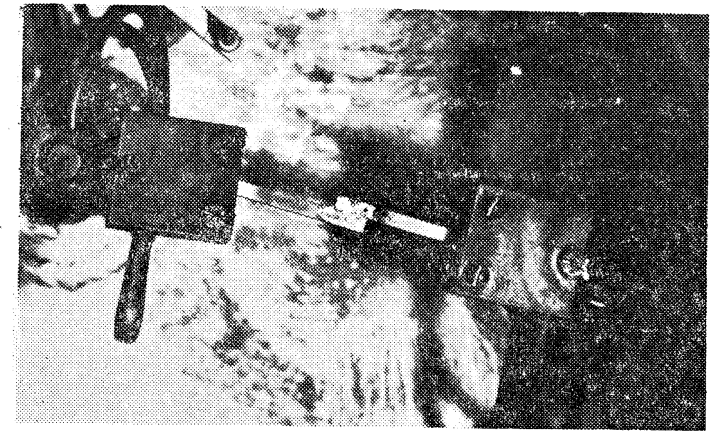

Fig. 10 TiC heater $(4.5 \times 4.5 \times 55 \mathrm{~mm})$ after $200 \mathrm{~min}$. of evaporation at a feeding rate of wire $24 \mathrm{mg} / \mathrm{min}$.

温度勾配を小さくしておく。通電加熱（平均 $6 \mathrm{~V}, 550$ A)をはじめて 約 10〜15 分間で蒸発温度に上げる。Ti 線を送るとヒ一タ面は始らされるが Al の如く著しく はない。Fig. 10に示したヒータは約 200 分、 $5 \mathrm{gr}$ 蒸発 後の蒸発源である。

ヒータの圧着部は送り込まれた Ti で新らしく生じた と思われる堆積物が、また Ti が直接当る部分は侵食の 跡が認められる。用いた TiC 棒は遊離炭素量 $0.01 \%$ 以下、炭素含有量 $\mathrm{C}_{1.0}$ の固溶体である。また焼結の 際結合剤を用いていない。 $\mathrm{Ti}$ 占連続して送り込まれる 之次第に Ti 含有量に富さ Sub carbide分生成し固相か ら液相に近づいてゆく。このために溶融点が下り変形し 㓎食の跡となるのであろう。ヒータは侵食によって切断 するよりも繰返觉し、加熱によってうける熱衝撃のため 柾折損することの方がより大きく寿命に影響を与党 た。したがって昇温には注意する必要があったが、その 後厚さ $2 \sim 3 \mathrm{~mm}$ 、幅 $10 \mathrm{~mm}$ のリボン状 $\mathrm{TiC}$ が得ら れるようになったので現在では $2 \times 10 \times 30 \mathrm{~mm}$ のヒー 安水冷ターミナルで両端から压着する支持法にしてい る。压着は外部から調節可能であり、圧着の調節と昇温 ひ注意すれば上述の欠陥は著しく減る。またりボン状ヒ 一タを用いるとヒータ面を小さくして余分の熱消費を減 らすことができるのでポンプの温度上昇を押えることに むなる。

ヒータは折損による寿命の制限が著しく少くなったの でこの場合侵食と堆積によって制限を受ける。

Fig. 11 に約 5 時間使用後のヒータを示す。（送り速 度 $24 \mathrm{mg} / \mathrm{min}$ ) life time (寿命) は現在約 7 時間であ る。

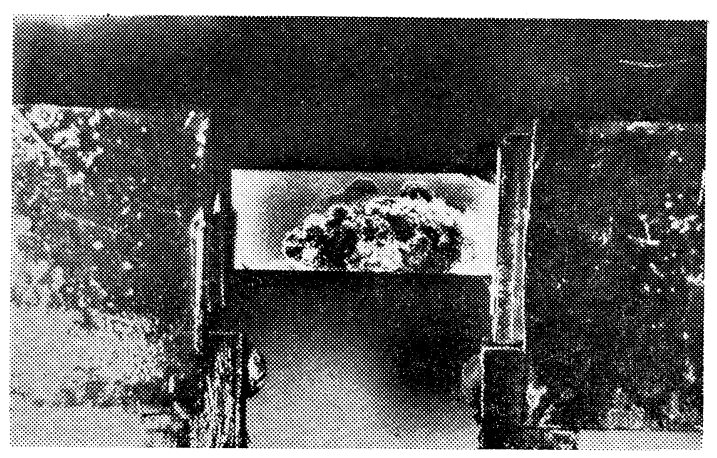

Fig. 11 Ribbon type TiC heater $(2 \times 10 \times 30 \mathrm{~mm})$ after evaporation of about 5 hours at a feeding rate of wire $24 \mathrm{mg} / \mathrm{min}$.

\section{4. 結 び}

TiCを蒸発源に用いたゲッタポンプを試作した。蒸発 源の特性と、ゲッタポンプに油拡散ポンプを併用した場 合の排気特性とについて以下のような所見が得られた。

1) $\mathrm{TiC}$ は $\mathrm{Ti}$ の蒸発源として有用である。

2) 油拡散ポンプを協力させることは極めて有効だ が、このとき油の逆拡散がゲッタポンプの排気速 夏に著しい影響を与えるからトラップを設けてこ の影響安取り除くことが重要である。またグリー ス、ゴムパッキング類の使用も排気速度に影響を なよぼす一因になることに注意しなければならな w。

終りにポンプ試作に当り多大の援助を賜わった䔰上真 空研究所高月博士、および TiC を提供していただき御 協力賜わった住友電工伊丹製作所三好課長、原研究員の 諸氏に深く感謝申乙あげ、また本研究に終始御援助いた だいた当所沢木技官（現松下電子工業研究所）また工作に 種々協力学惜しまれなかった工作室の諸氏に厚く御礼申 しあげます。

\section{[文献]}

1) Tabata, Iwata, Sawaki. : Vacuum. $7 / 8$ and 88 April (1959)

2) Milleron. N, : Vac. Tech. Trans., p 148. (1957)

3) Holland. L: Nature [London] 182, 851, (1958)

4) Degras. D. A : Le Vide No. 81. Mai-Juin, 128, (1959)

5）田畑、岩田、大工試季報 9, 3, (1958)

6) " " 10, 19, (1959)

7) Holland. L; Le Vide No. 81, Mai-Juin, 141, (1959)

8) デッタイオンポンプ (研究班) 真空 1，1，(1958) 